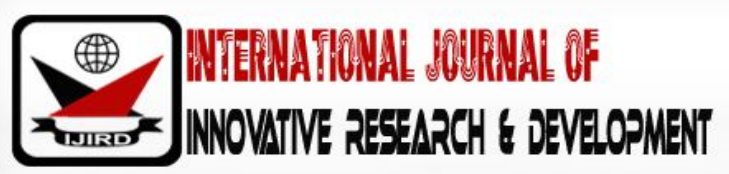

ISSN 2278 - 0211 (Online)

\section{Separation of Power in John Locke: A Critique}

\author{
Dr. Chukwuma Joseph Nnaemeka \\ Lecturer, Department of Philosophy, University of Nigeria \\ Uhuo Theophilus \\ Student, Department of Philosophy, University of Nigeria
}

\begin{abstract}
:
The quest for the best form of governmental system has led several countries of the world to engage themselves in the practice of one system of government or the other. This quest, with special concern to the political history of Britain, prompted the man John Locke to delve into formulation of the theories of governmental systems. These he did by tracing the social and economic situation of man in the state of nature, and finding out the need for man's social, economic, and political emancipation, he proposed a type of government which has the primary purpose of preserving the citizens' property. For the realization of this end, he employed some principles as tools for procuring this purpose. One of those tools is the concept of separation of power which simply suggests the division of political power among different domains, to avoid the fusion of power or absolute monarchism in the control of the Commonwealth. Given the assumed good intention of the idea, with the criticisms therein, this work aims at giving an in-depth analysis of the idea in order to determine the efficacy of that concept to procuring Locke's purpose of the commonwealth. Bearing in mind John Locke's reason for the formation of civil society, it therefore demands that for the actualization of Locke's purposes and precepts, an introduction of a new arm of government called an independent judiciary be made which has the very primary function of law interpretation as well as gaining or regaining one's lost liberty or property, as only this will make Locke's concept of separation of power yielding to his purpose of governmentThe need for the arm of government called Judiciary, which must be saddled with the responsibility of interpreting the Law of the land and checkmating the Executive and the legislative arms with the aim of ensuring the enthronement and sustenance of morality, can never be over emphasised.. This aim can be achieved by the use of the philosophical tool of analytic method to expose some loopholes in his idea especially the one of paying little or no attention to the judiciary, as its reconsideration will better the system of government he proposes.
\end{abstract}

Keywords: Separation, power, critique

\section{Introduction}

Man's social and political nature has prompted the quest for the appropriate way of governing the people. This as a result, led the social and political philosophers from the ancient era to the contemporary time to engage themselves in a rigorous postulation in form of political theories on the appropriate way of governance. In their postulations, there are some basic elements that defined their various strands. John Locke, an English modern thinker is one of these political philosophers that made remarkable contributions on how best a state should be governed. Locke understood like other political philosophers that when men come together politically, they create power. The problem of who should control the created power emerges, with different views from different philosophers. For Locke, power should not be placed in one hand but be entrusted in different terrains as the otherwise may lead to fusion of power. So, Locke advocates for separation of power in the state.

Though there are other philosophers of this concept "separation of power", the major concentration here is on this idea as it concerns John Locke's political theory. For Locke, the power of the state should be divided into three (3) different factions namely; legislative power (which he considers sovereign), executive power and the federative power. It is worthy of note that giving primacy to the legislative power which Locke sees as an arm closest to the people, means that the system of government he postulates can best be described as democracy.

This paper therefore aims at clarifying John Locke's idea of the concept, to determine how logical it is in relation to the end of his political,exposing the merits and demerits therein. It will also buttress a new reconsideration on governmental power sharing. 
We shall be limited to the idea of John Locke's concept of separation of powers, with some brief consideration of other proponents of the same concept.

analytic and evaluative method shall be employed as tools.

The idea of separation of power in governmental system has long been envisaged by several thinkers before the inception of John Locke's proposition of the concept. Given the above assertion, it will be of great necessity to trace the philosophical foundation/ origin of this concept "separation of power"

It is to be noted however, that the earliest trace of the idea was regarded not as the name it bears today, but was initially referred to as mixed government with checks and balances. Mixed government according to Wikipedia, is a form of government that combines the elements of democracy, aristocracy, and monarchy, making impossible their respective degeneration (conceived respectively as anarchy, oligarchy and tyranny). On the other hand, the system of checks and balances is seen as an important part of the constitution which provides that each of the three branches of government or combined element of different forms of government as the case maybe, can limit the power of the other, so that none possesses excess power. In the description of Plaso's ideal city, he gave different descriptions as to who should be the guardian, and who ought to be the judge as designated in his dialogues: The republic, and The Laws.

As to who will be the guardian(s), Plato asserts: "that as so far as their fitness for guarding is concerned, a noble youth and a well-bred dog are very much alike: meaning that both must be sharp-sighted, quick of foot to pursue the moment they perceive and strong enough to make captures and overcome opposition when necessary" 1 , "...To be a good and noble guardian of our city will be by nature philosophical and spirited and quick and strong". ${ }^{2}$ With this, one can rightly say that Plato demands a philosopher king who in his wisdom will also be young enough to face his responsibilities.

For a good judge Plato describes: "That one must not be young but old, one who has learnt late in life the nature of wickedness, not from taking note of wickedness dwelling in his heart, but having learned to understand wickedness in the heart of others, so that he has knowledge, though not personal experience of how evil it is ${ }^{3}$. Still on the judge, he notes: "The virtuous man, not the wicked one makes the wise judge"4 Here, he goes ethical to inform that one who ought to judge should be one who has learnt what it means to be either good or bad, a man of honesty.

From the above notes, it could be inferred that even in his ideal city, Plato opted for a type of government wherein the supposedly executive and legislators (the guardians) will be different from the judiciary (judges) even though he never mentioned it, nor did he mention his reasons. Plato made more supportive statement to this idea of separation of power during his discussion and criticism of oligarchy as he puts thus: "further do you think it right that in this constitution, the same men will play many parts?"5 Also, in another of his dialogues titled "The Laws", while discussing the success of Spartan leadership made the following observations: "... After that, a man who combined human nature with some of the powers of a god observed that your leadership was still in feverish state, so he blended the obstinacy and vigor of the Spartans with the prudent influence of age by giving the twenty-eight elders the same authority in making the same decision as kings. This is the formulae that turned your kingship into a mixture of right elements which ensured the stability of the rest of the state"6.

As early as 350BC, Aristotle, through his intellectual explorations, upheld a system of government that will not strictly border on any particular type of government. In his popular work titled "politik", He prescribed a system of government that characterizes a mixture of elements of different forms of government such as tyranny, aristocracy, oligarchy and democracy.

He observed what perversions that existed in each form of government as he puts thus: "of the above-mentioned forms, the perversions are as follows: of kingship, tyranny; of aristocracy, oligarchy; of constitutional government, democracy. For tyranny is a kind of monarchy which has in view the interest of the monarch only; oligarchy has in view the interest of the wealthy; democracy of the needy: none of them has the common good of all."7

With the above, it can be deduced that Aristotle opined that every form of government has a fault attached to it, and therefore, to curtail these prevailing deficiencies, good elements of each of the forms have to be merged together to form a single type of government. However, he opined that while these elements of the forms emerge to become one, each has to keep an eye on others to avoid over exercise of power by any of the forms of government as against others, and this informs the idea of checks and balances. Though Aristotle presumably meant well for the state through his proposition, he failed like Plato to give a name to the particular type of government he proposed.According to him,

All states have three elements, and the lawgiver has to regard what is expedient for each state. When they are well-ordered, the state is well- ordered, and as they differ from one another, constitutions differ. What is the first (1) element which deliberates about public affair; secondly(2) which is concerned with the magistrates and determine what they should be, over whom they should exercise their authority, and should be the mode of electing them, and thirdly (3) which has judicial power?8

All these in modern terminology correlate with the activities of the legislative (law-making), executive (law-enforcing), and judiciary (law-interpretation), respectively as the functions of government.

However, it is to be noted that while Aristotle identified these basic governmental power functions, he did not necessarily suggest that they are or should be exercised by entirely different branches, neither did he suggests that they are separate power-entities that should be independent of each other as founded in modern and contemporary understanding of the separation of power idea.

Polybiusa $12^{\text {th }}$ century historian gave one of the most comprehensive and distinctive contribution on the political stability of a state. In the book six(vi) of his popular book titled "The Histories", he devoted time to account through criticism 
and suggestions from the Roman constitution, what ought to be the best form of government. While tracing the origin of different constitutions, he observed that his predecessors had distinguished three kind of constitution which designates as kingship, aristocracy, and democracy. But for him, the classification of constitution should include the attendant degeneration of the above mentioned three constitutions.

For him then, there are six classifications of constitution namely; kingship which degenerates to tyranny, aristocracy which degenerates to oligarchy, and democracy which degenerates to mob-rule. As to the best form of constitution, he notes: "for it is plain that we must regard as the best constitution that which partakes all these three elements" 9 . It is to be noted that even though Polybius identified the attendant degeneration of earlier classification as forms of government in themselves, he still believes that the best constitutions are the three earlier classifications. But he disagreed that any of those earlier classifications can stand alone to make the best constitution. He believes that it is only the agglomeration of elements of the three best constitutions as in kingship, aristocracy, and democracy, can make the best form of government. One of the reasons why one form of government, that is, unmixed constitution produces unstable power, Polybius notes:

peculiar to it and inherent in its nature. For just as rust is the natural dissolvent of iron, woodworms and grubs to timber, by which they are destroyed without any external injury, but by that which is engendered in themselves; so in each constitution...because it will always be swiftly perverted into that particular form of evil, there is naturally engendered a particular vice inseparable from it: in kingship, it is absolutism; in aristocracy, it is oligarchy; in democracy lawless ferocity and violence: and to these vicious states, all these forms of government are, as I have said lately shows inevitably transformed ${ }^{10}$.

Here Polybius understood what danger it may pose to hand over the affairs of entire state to any particular group of people, whether it is the king, the wise and just, or the many, as all these have a peculiar evil inherent in them which may manifest at any time. Furthermore, Polybius extolled the Lycurgus law as helpful in the governance of a state, he states thus: "Lycurgus, as I said saw all these, and accordingly combined together all the excellences and distinctive features of the best constitutions, that no part should become unduly predominant, and be perverted into its kindred vice; and that each power being checked by the others, no one part should turn the scale or decisively out-balance the others; but that being accurately adjusted and in exact equilibrium, the whole might remain long and steady like a ship sailing close to the wind"11. This distinctive recapitulation of Lycurgus laws sounds closest to the idea of mixed government with checks and balances. Perhaps, Polybius opined for a type of constitution that power will not be concentrated in one particular element, but mixed of different characters that will be mindful of each other's operations.

\subsection{Iccolo Machiavelli}

This Italian $15^{\text {th }}$ century philosopher was popularly known for his two controversial texts namely: "The Prince", and "The Discourse". He was one of the major proponents of mixed government. His view was derived from his quest for a tranquil government which he saw as the best form of government ${ }^{12}$. From 'The Discourse", Machiavelli used three different countries' constitution to illustrate his point. Those countries include: (1) Rome which Machiavelli was advising on how to attain tranquility in their state. (2) Ancient Sparta which is governed by a king and small senate. The state restricts access to it from outsiders. It adopted the laws of Lycurgus which prescribed equality of property while insisting less in equality of rank ${ }^{13}$. (3) Modern Venice whose dwellers all participated in the government. But there were people who were taking to be eligible for administrative posts, and their head was called gentry. Real citizens were called gentlefolk while the alien was called the commoners, but none was denied anything but authority which is vested only on the gentry. It was in this manner of administration that tranquility was achieved in the state ${ }^{14}$.For the Roman constitution, he puts thus: "All things considered, therefore it is clear that it was necessary for Rome's legislators to do one or two things if she was to achieve tranquility like the aforesaid states: Either to emulate the Venetians and not employ its plebs in war, or like the Spartans, not to admit foreigners, or that she combines both elements"15.In the final analysis, Machiavelli through his suggestion to the Roman city could be said to have supported the idea of mixed government as a means of achieving tranquility in a city. However, he failed to give a detailed organization on the power of the state as he was majorly focused on the best way to attain a peaceful state. He also failed to take cognizance of the corrupting human desires always manifesting in the state power holders, as the possible cause of commotion in the city-state. In other words, he was focused on the external problems or causes of commotion in the state, and overlooked the internal riders of distress of the state. With this, he failed to give appropriate attention to the organization of power of the government in the state.

\subsection{Saint Thomas Aquinas (1225-1274)}

In his works, "summa theological", and "De Regno", Aquinas made a remarkable contribution on political theory. He was one of those that adored mixed constitution as the best form of government. In the summa theologica, while discussing the human law, Aquinas identified various forms of government namely; monarchy, that is, when the state is governed by one; aristocracy, a government by the best men or men of the highest rank, authoritative legal opinions and decrees of the senate. Another form according to him is oligarchy, a government by the few rich and powerful men, another form of government is that of the people which is called democracy. For him, there is also a tyrannical government which is altogether corrupt and which has no corresponding law ${ }^{16}$. On the question of which form of government is the best, Aquinas notes that: "finally, there 
is a form of government made up of all these and which is the best"17. With this observation from Aquinas, it is obvious that he identified all three simple forms of government in ancient Israel government as follows: a king, namely, Moses and his successors, who ruled over all, and this represents the element of monarchy, the seventy-two elders chosen for their virtue, is an example of the element of aristocracy, an election of the elders by and from all, is an element of democracy.

Aquinas stemmed from a different angle in his work, "De Regno" probably because of his Christian dogma as he shifted his opinion from mixed government as the best form of government. Here, he supported monarchy as the best form of government. According to him, it is a Christian notion of governing the universe, thus, the absolute monarchy of God. He stated that monarchy is the governmental form that corresponds best to the general order of the universe. He therefore declares that monarchy which is the right government of one ruler, is the form of political governance most in accord with nature, and for him, "whatever is in accord with nature is the best".

Though St Thomas Aquinas made a good contribution to state government, it can be said that he was very unstable with his opinion. He left his reasoning so much to dine with his faith, but that was after he had laid down opinion from his reasoning, and this made his work and political theory in general to suffer a big deal of contradiction as it throws into confusion anyone who wishes to delve into his political study. This as can be deduced, stemmed from his inconsistency as to which system of government is the best, for at some place, he said it is a mixture of good element of different forms of government, while in another place, he said that the best form of government is monarchy.

\subsection{Thomas Hobbes}

This 17th century English philosopher and a social contract theorist had the most distinct idea on the political power of the state. He was influenced by the political happening of his time which was surrounded by a protracted civil unrest. He delved into a proposition of what he thinks could possibly be the best form of government in a state. Different from other political thinkers, Hobbes was not a proponent of mixed constitutional regime. In his book titled "Leviathan", Hobbes opted for a monarchical form of government.

Hobbes' idea of monarchical form of government as the ideal form of government was informed by his conception of the hypothetical state of man in the state of nature where there exist neither laws nor any absolute power to checkmate the activities of man. The lawlessness of the state of nature made men behave any how they liked, and this ensure so many ills in the society. Hobbes therefore sorts for a way to curtail the animalistic behaviour of man while safeguarding his liberty and rights. He advocates for a form of government where the citizens surrender their rights and freedom to one man who will have supreme and sovereign power over all, and who will not be under but above the law. According to him, the sovereign leader or body will be known and called the "Leviathan". Stressing on the absolute power of the leviathan, Hobbes granted thus: "and covenant without sword are words and of no strength a man at all18". From the above information, it can be inferred that Hobbes sees the leviathan as an authoritarian who should be well equipped to protect the citizens. Hobbes believes that every man possesses power which will be given out as social contract in form of a unification of power onto a single individual. For Hobbes therefore, there is no separation of power, when the rights of the citizens have been unified and given to one individual as a sovereign entity. However, Hobbes failed to recognize that the man (leviathan) is the same person who was in the state of nature and who possesses those attributes like other men in the same state, and whose inherent selfish character may warrant his monarchical government to easily degenerate into tyranny. He also failed to take cognizance of what danger it may pose on the citizens' rights and freedom if the entire power of the state is entrusted on a single individual.

\subsection{John Locke's Concept of Separation of Power}

Locke identified three distinct power entities that exist for the proper governance of the state, they include; The Legislative Power, The Executive Power, and The Federative Power.

\subsection{The Legislative Power}

This is the Body which the members of the political society employ all their powers in making law of the community. ${ }^{19}$ According to Locke, "the legislative power is that which has a right to direct how the force of the commonwealth shall be employed for preserving the community and it members." ${ }^{20}$ Locke argues that for the realization of the end for which men unite in the community, the Legislative power is put into the hands of different individuals who by their assembling with other, elected or appointed persons, have the power to make Laws which when they have done, being separated again, they are themselves subject to the laws they have made; which is new and near tie upon them, to take care as they make them for the public good. Locke understood the legislative power as not only the supreme power in the community as it is seen as the power of the whole members who they represent, but also sacred and unalterable in the hands where the community has once placed it. Therefore, no edict or body whatsoever has the force and obligation of a law which has not its sanction from that legislative, which the public has chosen and appointed. ${ }^{21}$ Also no foreign or domestic subordinate power can discharge any member of the society from his obedience to the legislative, nor oblige him to any obedience contrary to the laws so enacted, or farther than they do allow. 22

However, while the legislative enjoy all these supremacies, Locke opines that whether it is placed in more than one hand, whether it is always in being or only by intervals, and, though it be supreme in every commonwealth, yet the following limitations endures: first, "it is not, nor can possibly be absolutely arbitrary over the lives and fortunes of the people as it can 
no more than those persons had in the state of nature before they entered into society and gave up to the community. And as the legislators are themselves subordinated to the law they are making, none can subject himself to the arbitrary power of another". ${ }^{3}$ Secondly, "the legislative or supreme authority cannot assume to itself a power to rule extemporary arbitrary Decrees, but it is bound to dispense justice, and decide the rights of the subjects by promulgated standing Laws, and known authorized judges." 24 This is because it will be hard to convince them of their mistakes in the absence of established judges, so, for Locke, it serves not as it ought, to determine the Rights, and fence the properties of those that live under it, especially where everyone is a judge or executioner, and, that at his own case.25Thirdly, the supreme power of the legislative cannot take from any man any part of his property without his own consent. Men in the society have property as well as the corresponding Right to them, which by the law of the community are theirs, that nobody has a right to take their substance, or any part of it from them, without their own consent; without this, they have no property at all. Since it is for the preservation of this that men resigned from their previous state to community, it therefore, necessarily demands that men should have property, without which there would be no need according to Locke, of entering into the political society. ${ }^{26}$ Finally, the legislative cannot transfer the power of making laws to any other hands. Because the power of the legislature is a delegated power from the people, they, who now possess it, cannot pass it over to others who they will. The people according to Locke have the obligation of paying obedience to the laws enacted by those they chose and authorized to do so. They were appointed, elected or authorized to make laws, and not to make anyone a legislator. ${ }^{27}$

The legislative converges according to an agreed time. On an important note, Locke opines that while the legislative power is seen as supreme, yet in the people resides more supreme power to remove or alter the legislative, when they find the legislative act contrary to the trust reposed in them. In the constitution is always found the proper regulation of legislative sitting, but in the cases of emergencies, the executive may act on their behalf. Because the laws that are at once, and in short time made by the legislative arm, have a constant and lasting force, and need a perpetual execution, there is of great necessity of a Body or Power who will always be in being, which should see to the execution of the law that are made, and remain in force. This leads to the second Body or Power of the commonwealth known as the Executive.

\subsection{The Executive Power}

As earlier stated, this power of the commonwealth sees to the execution of the laws made by the legislatures. For Locke: "it is the power that remains in force even while the legislative arm is on recess". ${ }^{28}$ Locke believes that this kind of power can be vested in one or more persons. According to him, in some commonwealths where the legislative is not always in being, and the executive power is vested in a single person who is also a member of the legislative arm; the person in a very tolerable sense may also be called supreme not because he has in himself supreme power which is exclusively for the Lawmaking Body, but because he has in him the supreme execution from whom all inferior magistrates derive their subordinate power. ${ }^{29}$ To the person that possesses this power, there is no superior legislative to him, and with this according to Locke, no law should be made without his consent, which cannot be expected to subject him to the other part of the legislative, and with this, he is properly supreme.

According to Locke, for the executive power placed on someone who does not share in the legislative, becomes subordinate and accountable to it, and thereby cannot be regarded as a supreme executive. Also, on the executive is placed with the power of convoking the legislative but not with the power of forcefully hindering the meeting and acting of the legislative. This implies that the executive reserves the power to hinder the assembling of the legislative if the constitution of the commonwealth grants them/ him such authority. It is to be noted according to Locke that the power of assembling and dismissing the legislative, placed on the executive, gives not the executive a superiority over it, but it is a fiduciary Trust, placed on him, for the safety of the people, in a case where the uncertainty, and variableness of humane affairs could not bear a steady fixed rule. As the executive is vested with all these responsibilities within the Commonwealth, it may, according to Locke, be incapable of taking care of the issues without. This brings about the third arm of government for Locke. This governmental power he called federative power.

\subsection{Federative Power}

For Locke, on entering a particular political society through a consented agreement with other men, one becomes one Body with those he entered into agreement with, and all men outside that agreement become aliens. He may still share anything with an alien but with the mind he had when he was in the natural state. When there is a controversy between a man within a state and another from without, and since the one within has resigned his rights with the powers of the Commonwealth, it is therefore expected that one of the powers of the Commonwealth should see to the settlement of such external controversy, and according to Locke, this power of the state can be called federative power 30 .

The Federative Power contains therefore the power of war and peace, Leagues and Alliances, and all the transactions with all persons and communities outside the Commonwealth. Locke understood the closeness of the functions of this power with that of the executive power when he notes that, "though these two powers be really distinct in themselves, yet, one comprehending the execution of municipal laws of the society within itself, upon all that are part of it; the other the management of security and interest of the public without, with all those that it may receive benefit or damage from, yet they are always almost united." 31 The major issue associated with the separation of both powers lie in their nature of operation, because while the nature of operation of the federative power requires that it hardly accepts directives from any antecedent, standing or positive 
laws, the opposite applies to the executive power. Therefore, it demands that the federative power be necessarily left to the prudence and wisdom of those whose hands it is in, to be managed for the public good ${ }^{32}$. Locke finally acknowledges the difficulty in separating the federative from the executive especially putting them in distinct hands. This is because both powers require force, and if it should be practicable, it means that the force of the Commonwealth would be under two distinct commands, and this Locke fears will certainly cause disorder and ruin in the Commonwealth.

In summary, Locke identifies three power entities in the Commonwealth viz: The Legislative, The Executive, and The Federative. Locke affirms that the legislative and the executive power come often to be separated. He however accepts the difficulty in separating the executive from the federative even to the extent of doubting its practicableness. ${ }^{33}$ In the next discussion, an exposition will be made concerning some overlaps that occur in practicing the system or method of separation of power opted for by John Locke.

\section{Prerogative}

On the meaning of prerogative, Locke states that it is nothing but a power in the hands of a prince to provide for the public good, in such cases, which depending upon the unforeseen and uncertain occurrences, certain and unalterable laws would not safely direct, whatsoever shall be done manifestly for the good of the people, and establishment of government upon its true foundation. ${ }^{34}$ This doctrine is a requirement that the good of the society demands that several things should be left to the discretion of him that has the executive power. According to Locke, "For the legislators not being to foresee and provide by Laws for all that may be useful to the community, the executor of the laws, having the power in his hands, has by common law of nature, a right to make use of it, for the good of the society, in many cases, where the municipal law has given no direction, till the legislative can conveniently be assembled to provide for it." 35 Locke also believes that there are things that the law can by no means provide for, and according to him, those must necessarily be left to the discretion of him that has the executive power in his hands, to be ordered by him, as the public good and advantage shall require. It is acceptable for Locke that the Laws themselves should in some cases give way to the executive power. Prerogative is strictly for accidental issues viz: "for many accidents may happen, wherein a rigid and strict observation of the laws may do harm; and a man may come down within the reach of the law, which makes no distinction of persons, by an action, that may deserve reward and pardon" 36 . With this, the ruler should have a power, in many cases, to mitigate the severity of the law, and pardon some offenders; since the end of government is the preservation of all, as much as may be even guilty are to be spared, where it can prove no prejudice to the innocent. Every prerogative made is questioned based on the end it tends to, for if it is not for the preservation of the state members, then, it is automatically nullified.

It can be noted summarily that the prerogative brings the executive power into several parts of the constitution, because not only that it acts on behalf of the legislature, it also acts as a judge, even though Locke failed to eminently recognize the duties of the judiciary to attaining the end of the Commonwealth, as he linked most of the judicial duties to the executive power, making the executive power function to be too cumbersome, and, thereby calling for a need for the modification and moderation of his concept of separation of power, so as to properly meet the end for which men resigned their right to the Commonwealth.

\subsection{An Evaluation of Locke's Concept of Separation of Power}

Granted that John Locke's political theory is a great and an overwhelming contribution to the development of democracy, there is a need however, to take some recapitulations of some democratic features therein in his theory, especially that of separation of powers. The thrust of this aspect is to critically review the aforementioned concept as found in Locke's political theory, in order to determine the logic of its democratic tendency, and to offer suggestions for its modification where and when necessary.

\subsection{The Test of Coherency in Locke's Idea}

There is no denying the fact that John Locke's political theory embodies democratic characters, hence, his theory of separation of power. But whether his theory of separation of power coheres with his general political theory, by which is meant whether his idea of power separation can grant the end for which men left or ought to leave the state of nature to unite into a single community, is yet to be gratified. It is to be noted however, that the major end of political society according to Locke is the preservation of property, by which he meant, Right to life, Liberty and Estate. ${ }^{37}$ In the state of nature according to Locke, "there are three things wanting, two of which are:

1. There wants an established, settled, known law, received and allowed by common consent to be the standard of Right and Wrong, and the Common measure to decide all controversies between them.

2. There wants a known and indifferent judge with authority to determine all differences according to established law". 38 With all these it could be said that in the state of nature, there was no established, settled and known law which everyone needs to abide by, and also, the fear of the repercussion of everyone being a judge in his or her own case necessitated the desire for a known and indifferent judge who shall take care of the controversies between people within the jurisdiction of the established and known law. The above problem as identified by Locke therefore demand that people enter a type of government or political system which will make provisions for both the body that will see to law-making, and also the body that will decide controversies between people under such laws. Following these reasons therefore, one can deduce that 
Locke's chief end of government necessarily needs the legislative body and the judiciary for its actualization. But because the society does not only need a law but also the implementation of the laws made by the legislature, there is also a need for the executive body, which shall also see to the internal and external affairs of the commonwealth. Though Locke opined that power-functions be separated from each other in the governmental system, he differed his opinion from the one mentioned above. Locke in his theory recognized three power-functional bodies in the state which include: the legislature, the executive and the federative. It is to be importantly noted that even though Locke understood the importance of judges or judicial function in the state, he never saw it as a separate power-function, but as part of the executive function. This can be ascertained in his statement: "And herein we have the original of the legislative, and executive power of civil society which is to judge by standing laws how far offences are to be punished...." 39 Locke understood the duties of the executive to include the execution of judgments of offences among members of the society who with consent, resigned their rights to it during the contract. Locke also affirms at some point that even the legislative body may also act as a judge or appoint someone to do so, as he puts thus: "... by setting up a judge on earth, with the authority to determine all the controversies, and redress the injuries that may happen to any member of the commonwealth; which judge is the legislative, or magistrates appointed by it." 40 Here, Locke did not only ascribe the judicial function to the legislative, but also, he undermined the idea of judicial independence which will be discussed later in this work. Locke himself understood some contradictions in his theory during his discussion of what he entitled prerogative. The concept of prerogative provides that the executive can make laws concerning urgent relevant issues which may occur when the legislatives are not in being. ${ }^{41}$ The contradiction arises according Locke, on the judgment of matters bordering on the laws made by executives. Locke had already maintained that the body that makes the law be separate from the body that judges under such law. It is to be noted that Locke regards the execution of the law to include judgment of controversies. To this contradiction which is, that at this point where the body that is supposed to make judgments becomes the body that makes the law, Locke says that, "appeal in such circumstance should be to heaven". ${ }^{42}$ This Locke's answer to this contradiction appears to be relatively abysmal and itching as he failed to give a justification of the existence of such entity called heaven, or at least establish how one can access it. This then takes one back to what Locke called a return to the state of nature, which he states thus: "For wherever any two men are, who have no standing Rule and a Common judge to appeal to on earth for the determination of controversies of Right between, there they are still in the state of nature, and under all inconveniencies of it." 43 Repeatedly, in his writings on political society, Locke emphasized on the need for a common judge to appeal to, but even at that, one can still deduce that the judges he meant revolved around or within the legislative and executive branch which are the two main separate bodies recognized by Locke.

There are three basic questions that need to be attended to in John Locke's political theory in order to determine the coherence of its argument. They are: Is there any necessary difference between the executives and judicative or judicial power which the judges and courts etymologically belong to? If there are, what is/ are the repercussion(s) of uniting them into one power-branch in a state whose chief aim is the preservation of property? But if there are none, what is the democratic tendency of the state whose one power branch has both the power to make laws, as well as judgment under such laws? To attempt these basic questions, references will be made to the post-Lockean philosopher who is regarded by many as the founding father of the modern version of separation of power. In his popular book titled The Spirit of Laws, Baron De Montesquieu made a remarkable contribution to the development and popularization of the concept "separation power". In Book XI, chapter6 of the text, Montesquieu differentiated the executive power from judicial power, as he describes the three power-branch of a state saying: "By virtue of the first, the prince or magistrate enacts temporary or perpetual laws, and amends or abrogates those that have been already enacted, by the second, he makes peace or war, send or receives embassies, establishes the public security, and provide against invasion. By the third, he punishes criminals, or determines the disputes that arise between individuals. The last prince we shall call the judiciary, but before that one, we simply call the other executive". ${ }^{44}$ Here, Montesquieu as can be seen traced the differences between these three power-branch by enumerating what functions each performs in the state. For Montesquieu, the chief end of any government is to ensure the liberty of the citizens; this liberty is inherent in Locke's property which ought to be preserved. It is therefore evidently necessary that by the virtue of their functions, the executive power is really different from the judicial power.

Montesquieu also answers the second question of whether there is any repercussion of uniting the above-mentioned power-branches into one power-branch. In his text mentioned earlier, Montesquieu opines that the judiciary be separated not only from the executive branch but also from the legislative branch, thus he puts: "Again, there is no Liberty, if the judiciary power be not separated from the legislative and the executive. Were it joined with the legislative, the life and liberty of the subject would be exposed to arbitrary control; for the judge would be the legislator. Were it joined to the executive power, the judge might behave with violence and oppression". 45 This Montesquieu's answer is just one among many consequences that it may result when the judicial power is united with the executive power. When the executive tries to perform its prerogative function, it will get the same result as when the judiciary is joined with the law-maker. Still on this question, Olayiwola A. Lawal, a Nigerian contemporary writer on this concept, 'separation of power', attested in line with Montesquieu saying: "In order to avoid tyranny and oppression, those who make Laws should not be those who punish offenders". 46 Moreover, given Locke's contradiction, there is a need that the body meant to make laws be separated from the body meant to judge under the same law. Without this, there may be fusion of power and possibly a return to the state of nature because of the tyrannical character that may be displayed by that body of power. With regard to the democratic tendency of Locke's political theory in relation to his idea of separation of power, if the powers be not separated from another, there is no doubt that the theme of the 
entire theory automatically changes to the attendant degeneration of monarchy as pointed out by Polybius which he calls tyranny. The answers above obviously indicate that there is a need for the modification or total reconstruction of Locke's concept of separation of power if it must retain the enhancement of its democratic character which the entire political theory seems to embody. This therefore calls for the introduction of a new power-branch called the judiciary, as a separate power branch or arm, and as a replacement of the federative power as designed by Locke, while its former jurisdictions will be ascribed to the executive branch, all for the purpose of the actualization of the end of government as propounded by John Locke.

\section{On The Need For A Working Judiciary}

Before delving into the importance of judiciary in a democratic government, it will be necessary that its meaning(s) be made known for proper clarity. Etymologically, the word 'judiciary' is derived from the Latin word "iudiciarius" meaning, belonging to a court of justice'. ${ }^{47}$ According to Memidex dictionary, the term 'judiciary' can be seen as persons who administer justice or a system of law court that administers justice and constitute the judicial branch of the government. This definition captures the basic elements of judiciary, namely: judge or justice, and, law court. According to Baron De Montesquieu, "the judiciary is the power-branch that punishes criminals, or determines the disputes that arise between individuals"48. This Montesquieu's definition captures the real nature of human society which is characterized by one form of conflict or the other. It is to be noted that even though the members of the society resigned their rights to the authority of the state, they did not resign their selfish and animalistic tendencies. This therefore demands that the institution of a body whose chief function will be the adjudication of cases is very necessary for the maintenance of peace and co-existence, as well as regaining one's lost liberty or property.

According to K.K Ghai in his article titled judiciary: its function and essential qualities, The judiciary is the organ of the government that has the responsibility to apply the laws to specific cases and settle all disputes. ${ }^{13}$ For Ghai, citizens should view the judiciary as the most important organ of the government because it acts as their protector against the possible excesses of the legislative and the executive organ. He argued that the role of the judiciary as the guardian and protector of the constitution, and the fundamental rights of the people makes it more respectable than other two organs. ${ }^{49}$

This draws one's attention or curiosity to what may consist of the roles or functions of the judiciary that makes it needful in a state whose chief aim is the preservation of property. The functions of the judiciary in this respect include the following:

- It grants justice to the people: according to N. S.S Iwe, "justice can be said to be a moral virtue which inclines the will to constantly and perpetually render to others, their due in time and place, and in a given set of circumstance".50In the state of nature, there is no commonly established law, nor is one known body meant to judge under any law, hence, everyone is a judge. This can reasonably be regarded as a threat to justice, as what may be obtainable is might is right principle, and will mean that weak people may always suffer injustice. But when a civil consented government is established with a known common law, as well as judges under such laws, the aggrieved citizens whether weak or strong, will no longer endure injustice, but can go to law court to seek for redress and possibly, a compensation. It will then be the duty of this body (judiciary) to award punishment to those who after trial are found guilty of violating the laws of the state or the rights of the people.

- Guardian of the constitution: As the constitution can rightly be said to be the supreme law of the land, and it is the primary responsibility of the judiciary to interpret and protect it, the judiciary for this reason, can conduct a judicial review on any law in order to determine whether or not it is still in accordance with the letters and spirit of the constitution. If any law is found ultra vires (unconstitutional), it is rejected by the judiciary, and it becomes invalid for future. This power of the judiciary is called the power of judicial review.

- Equity legislation: At a point, the judges depending upon their sense of justice, fairness, impartiality, honesty and wisdom, may turn to law-makers. This often happens where the law is silent or ambiguous, or appears to be inconsistent with some other laws of the land. This immediate decision making in the law court is what Ome calls "judicial activism". 51

- Exceptional duty in a federation: A federal system of government requires an exceptional important function from the judiciary as the guardian of the constitution, and the arbiter of disputes between the centre and the state. It is expected to act as an impartial umpire between the government at the centre and state government, as well as among states. All legal centre-state disputes are settled by the judiciary.

- It is the last arbiter of the common man: As already explained with regard to justice, the judiciary serves as the last hope of justice for every citizen of a state. During the adjudication of cases, the judiciary situates both weak and strong, the poor and the rich, the old and the young in one equal status in order to decide fairly and impartially whatever case that comes to it. With this, hope is won for those who otherwise would have sink in despair.

- With this few among many function and importance of judiciary, it can be said that it is highly needful especially in a state that seeks to preserve the rights and liberty of her citizens. Since conflict is inevitable as a result of clash of interest, there is need for a known and consented law, as well as the protection of such laws, and more importantly, a 
provision made for the settlement of such ever sure-to-come disputes between members of the state. As this branch has been established as a vital power-function in a democratic government, it is necessary to consider the extent to which it attends to its duty. Recall that the discharge of judicial duty as earlier stated requires honesty, impartiality, justice, wisdom and fairness for its essence to be felt. This implies that there is a tendency for the judges to deviate from their purpose. This possible deviation of a judge from his purpose means a deviation from honesty, impartiality, justice, fairness and wisdom. This deviation may be as a result of internal or external factor, internally, a judge may be said to be selfish, hungry, or generally corrupt. The external factors may be as a result of control from other power branches. Note that the internal factors as mentioned above may as well result from external factors; for instance, when a judge is not paid as due, he may compromise to enrich his pocket. Again, when a judge is appointed by the executive and confirmed by the legislative for a specific period of time, he (the judge) may tend to act to the desire of the one that appointed him, for either to be reappointed or to be promoted to a higher rank, or to avoid being forcefully resigned. All these factors may hinder the efficacy of judicial function; and this therefore calls for a situation where the judiciary is independent and free from the control and manipulations from other power branches of the government.

\section{Independence of Judiciary}

So many opinions have held on the meaning of the independence of the judiciary. According to a report issued by the Department of Human Rights and Rule of Law in Kosovo, "The independence of the judiciary is an integral part of democracy, intending to shield the judicial process from external influences and to provide full legal protection to all individualsgoing to any law court for whatever reason"52. This definition shows that the independence of the judiciary will not favour only the judicial officers but also the citizens that may request for their assistance. According to Joseph B. Diescho, "there is hardly any society on the planet today that does not in one way or the other fashion, cherish or call for more independence of the judicial organ of the state"53. For him, the independence of judiciary from influence and control of political actors is one of the hallmarks of constitutional democratic system.

Diescho identified that there are some contradictions and challenges in all systems that aspire to adhere or protect the principle of an independent judiciary. They include:

- The interlocking of state organ and their functions: This is the recognition of the fact that the judiciary inevitably participate in the political process. As the political environment produces the leaders who in turn appoint members of the judiciary, it is expected that there is fundamental relationship between the political actors and those who they assign the responsibility of interpreting the laws independently.

- The human factor: Although professionally trained jurists pledge to be impartial in their interpretation of laws, their personal bias and preferences may stand in the way of their true impartiality. However, the biases and preferences may be as a result of external factors or its fears.

- Difference in system priority and attitude towards the law: there are cultures where the law is supreme, whereas in others, the person who is the leader is more supreme than the law. This divergent attitude may constitute a problem for the independence of the judiciary. 54

These problems and other ones not mentioned here beg for an answer to the question, what is the possibility of a practicable independence of the judiciary? In other words, how can the independence of the judiciary be realistic? In the next topic, an effort is made to unravel some ways by which independent judiciary can be practiced or be possible.

\section{On The How of the Independence of the Judiciary}

Since the judiciary has been established as being of cardinal importance in the preservation of the citizens' rights and property, which means that it is very wanting in Locke's political society, it will therefore be of great necessity that we consider some factors that may trigger the efficacy of its functions. So many scholars have identified the need for judicial independence, but only few have tried to give a head-way to its realization. The focus here is to offer suggestions on the possible ways of gaining independence for the judiciary, as it fosters the preservation of citizen's rights, liberty and property which is the sole aim of John Locke's political society. Despite all difficulties in the practicableness or the total realization of an independent judiciary, there are still some measures to take in order to realize independency for the judicial arm of government. These measures include the following.

\subsection{Inculcation of international laws in a country's constitution}

Some contents of many universal and regional laws uphold the idea that competent court of laws be independent so as to ensure that citizens' rights are guaranteed. For instance, article 14(1) of the International Covenant on Civil and Political Right states that: "all persons shall be equal before the courts and tribunal...in the determination of any criminal charge against him or of his rights and obligation in a suit of law, everyone shall be entitled to a fair and public hearing by a competent, independent and impartial tribunal established by law"55.This international enactment recognizes the intricacies of judicial practice and how the judicial independence can boost the confidence in its result. This also shows to a great extent 
how a citizen's right is being revered as emphasized by Locke in his political theory. It can as well be noted here that only an independent judiciary is able to render judgment impartially on the basis of law. Furthermore, according to Article 26 of the African Charter on Human and Peoples' Right, the State Parties shall have the duty to guarantee the independence of the courts ${ }^{56}$. By the state parties here, it is to be understood as the formers of the constitution. With the inclusion and adherence to all these directives from the international bodies to a country's constitution, there is sure to be an independent judiciary.

\subsection{Guaranteed Security of Tenure of Judges}

Another important way of enhancing the independence of the judiciary is by ensuring that the appointment of any judicial officer will endure till the appointee reaches the age of retirement which differs from one country and another. For instance, like any other worker in the United States of America, their judges retire at the age of 65 . This will ensure that the judges especially willcarry out their constitutional duties without fear or favour, and without any special regard to the authority that appointed him. This is not to debunk a judge's loyalty to a higher authority, but that loyalty of whatsoever should not stand against justice. If any judge is appointed for a specific period of time, he is bound to act or judge always in the favour of the authority that appointed him for either the purpose of re-appointment or a new appointment to a higher level. But if there is no specific tenure, he is free to deliver justice in all cases.

\subsection{Respect for Profession Instead of Hierarchy}

The threat to the independence of the judiciary does not only come from the external body, hence, there are also hindrances to an independent judiciary within the judiciary itself. At some point, the lower level prosecutors or lawyers tend to take instructions from the higher-in-hierarchy professionals in their handling of cases. It may as well take the form of attack by the higher judges on the lower ones. It should be noted that in the phase of justice, all is equal. The emphasis in the legal profession should therefore be on the importance of the profession to the general society, and not on hierarchy, because a defeat of this branch of government is a defeat to the whole society.

\subsection{Financial Autonomy and Sufficient Resources}

The judiciary needs adequate resources to discharge its function appropriately. Since the judiciary receives its resources from the national budget which is always determined by either the legislative or executive, it is essential that those outlining and approving the state budget take the needs of the judiciary into consideration. This is important because inadequate resources may render judiciary vulnerable to corruption which is one of the biggest threats to judicial independence. To this end, states should create within the judiciary, bodies in charge of administering judicial resources, thus, reinforcing the autonomy of the judicial organ.

\subsection{Professional secrecy and immunity}

The judiciary shall be bound by professional secrecy with regard to their deliberation and confidential information acquired in the course of their duties other than in proceedings, and shall not be compelled to testify on such matters.In conclusion, as human errors are inevitable, especially when human interest is in conflict with the claims of others, or when this interest clash with others', it requires then that a judiciary independently interprets the law, and the assumptions which underlie it, so as to appropriately preserve the rights and liberties of the citizens, even as justice prevails.

\section{Summary and Conclusion}

Locke's political theory was traced from his perceived pre-condition of man in the state of nature, where there is no common established law, and no common judge, who may curtail the selfish character, and animalistic and monstrous tendencies inherently in men as Thomas Hobbes would point out.

Locke's introduction of the concept of separation of powers in his political theory was to remedy these inconveniencies of the state of nature. He introduced different power branches namely; the legislative, the executive and the federative. While the legislative makes law, the executive executes the law, and takes care of all the affairs within the commonwealth including the judgment of offences and punishment of offenders. And the federative body concern itself with matters outside the commonwealth but as it concerns the state or her members. In his theory, Locke maintained that the legislative be separated from the executive. Locke also introduced the concept of prerogative, which given the non-frequent in being of the legislative, demands that the executive become law-maker when the circumstance demands for it. This concept and the negligence of the judicial body brought a big contradiction and incoherency to Locke's theory as was expatiated in this paper. Locke's major aim of entering the political society is the preservation of citizen's property as already explained above.

Given the need for the realization of this major end of Locke's political society, and the introduction of the concept of separation of power as a major tool for procuring such end, this paper looked at the efficacy of this tool as propounded by Locke, in the preservation of citizens' property. After every scrutiny, a need arose for the modification of Locke's concept, and this led to the introduction of judiciary as a necessary separate-power-branch and as a replacement of the federative power whose function will henceforth be performed by the executive. The importance of this new power branch in Locke's type of government will require that it be separate and independent of the other two power branches.Given the end of political 
society in Locke's political theory, one could be right to say that he offered a good example of democratic society. However, the tool he employed for the realization of this advantageous end can be said to be inherently obnoxious as well as incoherent with the purpose it is meant to achieve. This therefore means that Locke's idea of separation of power does not cohere with his theory of political society especially as it concerns the end or purpose of that society, as it cannot remedy the inconveniencies of the state of nature which prompted men to unite together. The reason for all these odds was as result of Locke's negligence of the body naturally meant for the adjudication of cases which is called the judiciary. This necessitated the focus given to the judicial arm of government in this work, which will make a better separate-power in the position of the federative in Locke's theory. The judicial arm in fulfilling this task requires independency. Judicial independence can be said to be the antithesis of arbitrary rule: it is the opposite of despotic system of governance; it is governance through and in accord with the law. It is the locus of the tools for the preservation of citizen's property, and therefore of primary importance in Locke's political society.

\section{References:}

1. Plato, The Republic, trans. A.D Lindsay (New York: E.P Dutton Company Inc., 1950), 67.

2. Plato, The Republic, 70.

3. Plato, The Republic, 116.

4. Plato, The Republic, 116.

5. Plato, The Republic, 307.

6. Plato, The Law, trans. T.V Sander (London: Penguin Books Ltd, 1970), 95.

7. Aristotle, Politics, ed. Stephen Everson (London: Cambridge university press, 1966), 127.

8. Aristotle, Politics, trans. Benjamin Jowett (London: Clarendon press, 1905), 175.

9. Polybius, The Histories, trans. E.S Shuckburgh (Cambridge: parentheses publication, 2002), 350.

10. Polybius, The Histories, 355.

11. Polybius, The Histories, 355.

12. Niccolo, Machiavelli, The Discourse, ed. Benard Crick(London: Penguin Books Ltd,

13. 1974), 120 .

14. Niccolo, Machiavelli, The Discourse, 120.

15. Niccolo, Machiavelli, The Discourse, 119.

16. Niccolo, Machiavelli, The Discourse, 121.

17. Aquinas, Thomas, Summa Theologica, trans. Fathers of the English Dominican Province

18. (Ohio: Benziger Bros. Edition, 1947), 1361

19. Aquinas, Thomas, Summa Theologica, 1361.

20. Thomas, Hobbes, Leviathan ed. Hutchuius, SR.M (Chicago: Encyclopedia Britannica Inc,

21. 1952), 104.

22. Locke John, Two Treatise of Government,354.

23. Locke John, Two Treatise of Government,364.

24. Locke John, Two Treatise of Government,356.

25. Locke John, Two Treatise of Government,357.

26. Locke John, Two Treatise of Government, 357.

27. Locke John, Two Treatise of Government,358.

28. Locke John, Two Treatise of Government,359.

29. Locke John, Two Treatise of Government, 360.

30. Locke John, Two Treatise of Government,362.

31. Locke John, Two Treatise of Government,365.

32. Locke John, Two Treatise of Government,368.

33. Locke John, Two Treatise of Government,365.

34. Locke John, Two Treatise of Government,365.

35. Locke John, Two Treatise of Government,366.

36. Locke John, Two Treatise of Government,366.

37. Locke John, Two Treatise of Government, 373.

38. Locke John, Two Treatise of Government, 374.

39. Locke John, Two Treatise of Government, 375.

40. Locke John, Two Treatise of Government (E.d) peter Laslett (London: Cambridge University Press, 2006), 350.

41. Locke John, Two Treatise of Government, 351.

42. Locke John, Two Treatise of Government, 325.

43. Locke John, Two Treatise of Government, 325.

44. Locke John, Two Treatise of Government, 379.

45. Locke John, Two Treatise of Government, 379.

46. Locke John, Two Treatise of Government, 326.

47. Baron De Montesquieu, The Spirit of Laws (Chicago: Great Book series), 69-70. 
48. Baron De Montesquieu, the Spirit of Laws, 70.

49. Olayiwola A. Lawal, 'O'Level Government of West Africa (Ibadan: Onibonoje publisher,

50. 1976), 14.

51. Online Etymology Dictionary, retrieved June 22, 2017 (Douglas Harper Custom Logo

52. Design, 2001).

53. Baron De Montesquieu, The Spirit of Laws. (Chicago: Great Book series), 69.

54. Ghai K. K, Judiciary: Its Function and Essential Qualities (Benin: Article Library Press,

55. 2016), 3.

56. Ghai K. K, Judiciary: Its Function and Essential Qualities, 4.

57. Charles Chukwudozie, Introduction to Human Rights and Social Justice, (Enugu: Ochumba

58. Printing and Company Limited, 1999), 7.

59. Ome E.M Lecture Note, delivered on May 30, 2017.

60. Department of Human Rights and Rule of Law, The independence of Judiciary and Its Role

61. in the Protection of Human Rights, Kosovo, 1997,1.

62. Diescho Joseph B. The paradigm of an Independent Judiciary, International Journal of

63. Human Rights and Rule of Law 12 (2004): 37

64. Diescho Joseph B. International Journal of Human Right and Rule of Law 12, 42. 